\title{
Karakteristik yang Berhubungan dengan Persalinan Sectio Caesarea di RSUD H Abdul Manap Kota Jambi Tahun 2019
}

\author{
Rini Mayasari \\ Akademi Kebidanan Budi Mulia Jambi
}

\author{
Informasi Artikel : \\ Diterima : 01 Mei 2020 \\ Direvisi : 12 Mei 2020 \\ Disetujui : 23 Mei 2020 \\ *Korespondensi Penulis : \\ rinimayasari8585@gmail.com
}

\begin{abstract}
A B S T R A K
Angka persalinan Sectio Caesarea di Amerika Serikat telah meningkat empat kali lipat, dari 5,5 per 100 kelahiran pada tahun 1970 menjadi 22,7 per 100 kelahiran pada tahun 1985. Insidensi Sectio Caesarea dalam masing-masing unit obstetrik bergantung pada populasi pasien dan sikap dokter. Sekarang ini angkanya berkisar antara 10 sampai 40 persen dari semua kelahiran, karena seksio sesaria telah ikut mengurangi angka kematian perinatal. Tujuan penelitian ini adalah untuk mengetahui faktor-faktor yang berhubungan dengan persalinan operasi Sectio Caesarea pada persalinan ibu di RSUD H Abdul Manap Jambi. Hipotesis yang diajukan ialah adanya hubungan antara umur, Tinggi Badan dan Malpresentasi dengan tindakan persalinan Sectio Caesarea. Penelitian ini menggunakan metode survey analitik dengan pendekatan cross sectional, menggunakan data primer dari wawancara terpimpin dengan kuesioner serta data sekunder dari rekam medis. Penelitian ini dilaksanakan di RSUD H Abdul Manap Jambi September-Nov 2019 . Populasi penelitian ini ialah seluruh ibu yang melahirkan di RSUD H Abdul Manap Kota Jambi 264 responden. Sedangkan sampel pada penelitian ini berjumlah 264 responden yang diambil menggunakan tehnik consecutive sampling. Analisis bivariat menggunakan uji statistik chi square dan fisher dengan derajat kemaknaan $(\alpha)=0,05$. Hasil penelitian memperlihatkan bahwa faktor-faktor yang berhubungan dengan tindakan persalinan Sectio Caesarea yaitu diantaranya; usia ibu (p $0,318)$, Tinggi Badan $(0,000)$ dan Malpresentasi $(0,128)$. Dengan demikian maka disarankan bagi ibu yang memiliki risiko usia $\leq 20$ tahun dan $\geq 35$ tahun, paritas 1 dan $\geq 4$ anak, serta mengalami anemia saat hamil supaya mempersiapkan diri untuk perencanaan operasi Sectio Caesarea.
\end{abstract}

\section{Kata Kunci: Persalinan, Operasi Sectio Caesarea}

\section{ABSTRACT}

The rate of cesarean delivery in the United States has quadrupled, from 5.5 per 100 births in 1970 to 22.7 per 100 births in 1985 . The incidence of cesarean section in each obstetric unit depends on the patient population and physician attitudes. At present the figure ranges from 10 to 40 percent of all births, because cesarean section has helped reduce perinatal mortality. The purpose of this study was to determine the factors associated with cesarean section delivery labor in maternal labor at $H$ Abdul Manap Hospital Jambi. The hypothesis is that there is a relationship between age, height and achievement malls with caesarean delivery. This research uses analytic survey method with cross sectional approach, using primary data from guided interviews with questionnaires and secondary data from medical records. This research was conducted at H Abdul Manap Hospital Jambi, September-Nov 2019. The population of this study was all mothers who gave birth H. Abdul Manap in Jambi City Hospital 264 respondents. While the sample in this study amounted to 264 
respondents taken using consecutive sampling techniques. Bivariate analysis used chi square and fisher statistic test with significance level $(\alpha)=0.05$. The results showed that the factors related to Caesarean section deliveries included; maternal age ( $p$. 0.318), Height (0,000) and Performance Mall (0.128). Thus it is recommended for mothers who have a risk of age $\leq 20$ years and $\geq$ 35 years, parity 1 and anak 4 children, and have anemia during pregnancy to prepare themselves for planning cesarean section operations.

\section{Keyword: Parturution, Seksio Caesarea}

\section{PENDAHULUAN}

Sectio Caesarea dapat dikatakan sebagai operasi yang sederhana, dan saat bersamaan disebut juga sebagai operasi yang paling dramatis di antara operasi besar. Dinding perut diiris, secara vertikal atau horisontal, selebar lima belas sentimeter, dinding uterus diiris, sekali lagi secara vertikal atau horisontal, dengan lebar yang hampir sama, sang bayi dan placentanya dikeluarkan , kemudian irisan itu dijahit kembali. ${ }^{1}$

Sectio caesarea berasal dari bahasa Latin caedere yang berarti memotong atau menyayat. Dalam ilmu obstetrik, istilah tersebut mengacu pada tindakan pembedahan yang bertujuan melahirkan bayi dengan membuka dinding perut dan rahim ibu. Sectio Caesarea pertama kali disebut sebagai cara melahirkan bayi dalam dunia kedokteran di tahun 1794, tetapi saat itu melahirkan dengan bedah caesar memiliki risiko kematian ibu yang besar. Hal tersebut disebabkan tidak tersedianya peralatan, obat bius, antibiotik, maupun teknik pembedahan yang memadai. Sekitar tahun 1980-an bedah Sectio Caesarea, baik yang direncanakan (elective caesar) maupun yang baru diputuskan saat persalinan saat persalinan berlangsung (emergency caesar), mulai memasyarakat di bidang kebidanan. $^{2}$

Angka persalinan Sectio Caesarea di Amerika Serikat telah meningkat empat kali lipat, dari 5,5 per 100 kelahiran pada tahun 1970 menjadi 22,7 per 100 kelahiran pada tahun 1985 . Insidensi Sectio Caesarea dalam masing-masing unit obstetrik bergantung pada populasi pasien dan sikap dokter. Sekarang ini angkanya berkisar antara 10 sampai 40 persen dari semua kelahiran, karena seksio sesaria telah ikut mengurangi angka kematian perinatal . ${ }^{2}$

Angka persalinan Sectio Caesarea yang ada sebenarnya terlalu tinggi sehingga ada berbagai upaya untuk menguranginya karena meningkatnya morbiditas dan mortalitas ibu.
Pada kasus Sectio Caesarea angka mortalitas dua kali angka pada pelahiran pervaginam, disamping itu angka morbiditas yang terjadi akibat infeksi, kehilangan darah, dan kerusakan organ internal lebih tinggi pada persalinan Sectio Caesarea. Mengacu pada WHO, Indonesia mempunyai kriteria angka Sectio Caesarea standar antara 15 $20 \%$ untuk RS rujukan. Angka itu dipakai juga untuk pertimbangan akreditisasi Rumah Sakit. ${ }^{3}$

Di Indonesia , meskipun survei Demografi dan Kesehatan tahun 1997 dan tahun 2002-2003 mencatat angka persalinan bedah Sectio Caesarea secara nasional hanya berjumlah kurang lebih $4 \%$ dari jumlah total persalinan , berbagai survei dan penelitian lain menemukan bahwa presentase persalinan Sectio Caesarea pada rumah sakit-rumah sakit di kota besar seperti Jakarta dan Bali berada jauh di atas angka tersebut. Secara umum jumlah persalinan Sectio Caesarea di rumah sakit pemerintah adalah sekitar 20-25\% dari total persalinan, sedangkan di rumah sakit swasta jumlahnya sangat tinggi yaitu sekitar 30-80 \% dari total persalinan . ${ }^{4}$

Dari berbagai penyulit persalinan yang terjadi akan diputuskan untuk melaksanakan operasi Sectio Caesarea, operasi ini harus dipahami sebagai alternatif persalinan ketika jalan lahir normal tidak bisa lagi. Sebenarnya melahirkan dengan operasi Sectio Caesarea ditunjukkan untuk indikasi medis tertentu, yang terbagi atas indikasi untuk ibu dan indikasi untuk bayi. Semua indikasi itu berdasarkan kondisi medis dari ibu atau bayi yang memerlukan tindakan melahirkan secara caesar. ${ }^{5}$

Sectio caesaria atau bedah caesar harus dipahami sebagai alternatif persalinan ketika jalan normal tidak bisa lagi. Meskipun 90\% persalinan termasuk kategori normal atau tanpa komplikasi persalinan, namun masih banyak ibuibu memilih jalan operasi seksio sesaria dalam persalinannya demi keselamatan ibu dan bayi. Apapun yang menjadi kesulitan persalinan, penanganan selalu berpegang teguh pada prioritas keselamatan ibu dan bayi. Sectio Caesarea merupakan cara pembedahan yang telah tua 
umurnya di bidang obstetrik dan mempunyai riwayat yang unik. Ini merupakan pilihan persalinan yang terakhir setelah dipertimbangkan cara-cara persalinan pervaginam tidak layak untuk dikerjakan. ${ }^{6}$

Data yang didapatkan dari RSUD H Abdul manap Kota Jambi menunjukkan kasus persalinan Sectio Caesarea pada tahun 2017 menunjukkan prosentase sebesar $60,52 \%$ dari 694 persalinan yaitu sebanyak 420 persalinan Sectio Caesarea. Kemudian pada tahun 2018 jumlah persalinan Sectio Caesarea meningkat menjadi 66,91 \% dari 792 persalinan yaitu sebanyak 530 persalinan Sectio Caesarea. 7

Semakin bertambah banyaknya jumlah operasi Sectio Caesarea di Indonesia, khususnya yang ada di RSUD H Abdul manap Kota jambi, maka peneliti tertarik untuk mencari tahu tentang Karakteristik yang berhubungan dengan persalinan Sectio Caesarea di RSUD H Abdul Manap Kota Jambi Tahun 2019.

\section{METODE PENELITIAN}

Penelitian ini termasuk penelitian survey explanatory, karena pada penelitian ini tujuannya adalah dalam rangka memberi penjelasan mengenai hubungan kasual dan pengujian hipotesis. Pendekatan yang digunakan dalam penelitian ini adalah cross sectional study karena probabilitas penemuan kasus tinadakan Sectio Caesarea tinggi yaitu sebesar $66,91 \%$ pada tahun 2019, sehingga penemuan kasus lebih mudah. ${ }^{8}$

Dalam penelitian cross sectional ini yang menjadi variabel bebas yaitu Usia ibu, paritas, tinggi badan ibu, jumlah pemeriksaan kehamilan, riwayat obstetri ibu, kejadian ketuban pecah dini, riwayat penyakit hipertensi ibu, riwayat penyakit asma ibu, riwayat penyakit diabetes ibu.Sedangkan yang menjadi variabel terikat yaitu Persalinan Sectio Caesarea. ${ }^{8}$

\section{HASIL PENELITIAN}

\section{Analisis Univariat}

Analisa ini dilakukan untuk mengetahui distribusi frekuensi variabel dependen seksio cesarea dan variabel independen malprestasi, tinggi badan dan pertus lamal. Hasil penelitian terhadap masing-masing variabel akan diuraikan di bawah ini :

\section{Variabel Dependen}

Tabel 1 Distribusi Frekuensi Persalinan Sectio Caesarea di RSUD H Abdul Manap Kota Jambi Tahun 2019

\begin{tabular}{cccc}
\hline No & Sectio Caesarea & Frekuensi & $\%$ \\
\hline 1 & Ya & 123 & 46,6 \\
2 & Tidak & 141 & 53,4 \\
\hline & Jumlah & 264 & 100 \\
\hline
\end{tabular}

Berdasarkan tabel 1 diatas dari 264 responden didapatkan ibu dengan persalinan seksio sesaria berjumlah 123 orang $(46,6 \%)$ dan ibu yang tidak sesaria berjumlah 141 orang $(53,4 \%)$.

\section{Variabel Independen}

\section{a. Umur}

Tabel 2 Distribusi Frekuensi Responden Berdasarkan Malpresentasi di RSUD H Abdul Manap Kota Jambi Tahun 2019

\begin{tabular}{c|c|c|c|}
\hline No & umur & Frekuensi & $\%$ \\
\hline 1 & resiko rendah & 46 & 17,4 \\
\hline 2 & resiko tinggi & 218 & 82,6 \\
\hline & Jumlah & 264 & 100 \\
\hline
\end{tabular}

Berdasarkan tabel 2 diatas dari 264 responden didapatkan ibu yang mengalami resiko rendah sebanyak $46(17,4 \%)$ responden lebih kecil dibandingkan dengan ibu yang resiko tinggi sebanyak $218(82,6 \%)$.

\section{b. Tinggi Badan}

Tabel 3 Distribusi Frekuensi Responden Berdasarkan Tinggi Badan di RSUD H Abdul Manap Kota Jambi Tahun 2019

\begin{tabular}{c|c|cc|}
\hline No & Tinggi Badan Ibu & Frekuensi & $\%$ \\
\hline 1 & Resiko Tinggi & 238 & 58,6 \\
\hline 2 & Resiko Rendah & 26 & 41,4 \\
\hline & Jumlah & 264 & 100 \\
\hline
\end{tabular}

Berdasarkan tabel 3 diatas diatas dari 264 responden dapat diketahui bahwa TB ibu resiko tinggi sebanyak $238(90,2 \%)$ responden lebih bear dibandingkan dengan TB resiko sebanyak 26 responden $(9,8 \%)$

\section{c. Malpresentasi}

Tabel 4 Distribusi Frekuensi Responden Berdasarkan Malpresentasi di RSUD H Abdul Manap Kota Jambi Tahun 2019 


\begin{tabular}{cccc}
\hline No & Malpresentasi & Frekuensi & $\%$ \\
\hline 1 & ya & 75 & 28,4 \\
2 & tidak & 189 & 71,6 \\
\hline & Jumlah & 264 & 100 \\
\hline
\end{tabular}

diatas dari 264 responden dapat diketahui bahwa ibu yang Malpresentasi sebanyak 75 ( $28,4 \%$ ) rsponden lebih kecil diandingkan Tidak Malpresentasi sebanyak 189 responden $(71,6 \%)$.

\section{Analisis Bivariat}

Analisa ini dilakukan untuk mengetahui hubungan antara variabel dependen seksio sesaria dengan variabel independen Umur, Tinggi badan, dan pendidikan. Penelitian ini dilakukan untuk melihat apakah ada hubungan antara variabel independen dan variabel dependen dengan menggunakan uji statistik Chi-Square dengan $\alpha=0,05$ dan $\mathrm{df}=1$ dengan batas kemaknaan $p$ value $\leq 0,05$ ada hubungan yang bermakna, dan $p$ value $>0,05$ tidak bermakna.

a. Hubungan Umur dengan persalinan seksio cesaria di RSUD Abdul Manap Kota Jambi Tahun 2019

Tabel 5 Distrubusi Hubungan Umur dengan Kejadian Sectio Caesarea di RSUD Abdul Manap Kota Jambi Tahun 2019

\begin{tabular}{|c|c|c|c|c|c|c|c|}
\hline \multirow{3}{*}{$\begin{array}{l}\mathbf{N} \\
\mathbf{0}\end{array}$} & \multirow{3}{*}{ Umur } & \multicolumn{4}{|c|}{$\begin{array}{c}\text { Persalinan Sectio } \\
\text { Caesarea }\end{array}$} & \multirow{3}{*}{ Total } & \multirow{3}{*}{$\begin{array}{c}P \\
\text { Value }\end{array}$} \\
\hline & & \multicolumn{2}{|c|}{ Ya } & \multicolumn{2}{|c|}{ Tidak } & & \\
\hline & & $\mathbf{N}$ & $\%$ & $\mathbf{N}$ & $\%$ & & \\
\hline 1 & $\begin{array}{l}\text { Resiko } \\
\text { Rendah }\end{array}$ & 25 & 54,3 & 21 & 45,7 & 46 & \multirow[t]{3}{*}{0,318} \\
\hline \multirow[t]{2}{*}{2} & $\begin{array}{l}\text { Resiko } \\
\text { Tinggi }\end{array}$ & 98 & 45 & 120 & 55 & 218 & \\
\hline & Jumlah & 123 & & 141 & & 246 & \\
\hline
\end{tabular}

Berdasarkan Tabel 5 diatas dapat dilihat bahwa dari 246 responden ibu yang umur resiko rendah dengan tindakan persalinan SC sebanyak $25(54,3 \%)$ orang lebih sedikit dibandingkan dengan responden yang mengalami umur resiko tinggi SC yaitu dari 98 (45\%)

Berdasarkan uji chi Square didapatkan nilai $\mathrm{p}$ value $=0,318<$ a 0,005 . Artinya menunjukkan bahwa tidak ada hubungan yang bermakna antara Umur dengan persalinan sectio cesarea dengan demikian hipotesis yang menyatakan ada hubungan umur dengan persalinan sectio cesarea tidak terbukti secara statistik.

\section{b. Hubungan Tinggi Badan dengan} Persalinan Sectio Caesarea

Tabel 6 Distrubusi Hubungan Tinggi Badan dengan Kejadian Sectio Cessaria di RSUD H Abdul Manap Kota Prabumulih Tahun 2019

\begin{tabular}{|c|c|c|c|c|c|c|c|}
\hline \multirow{3}{*}{$\begin{array}{l}\mathbf{N} \\
\mathbf{O}\end{array}$} & \multirow{3}{*}{$\begin{array}{l}\text { Tinggi } \\
\text { Badan }\end{array}$} & \multicolumn{4}{|c|}{$\begin{array}{c}\text { Persalinan Seksio } \\
\text { Cessaria }\end{array}$} & \multirow{3}{*}{ Total } & \multirow{3}{*}{$\begin{array}{c}P \\
\text { Value }\end{array}$} \\
\hline & & \multicolumn{2}{|c|}{ Ya } & \multicolumn{2}{|c|}{ Tidak } & & \\
\hline & & $\mathbf{N}$ & $\%$ & $\mathbf{N}$ & $\%$ & & \\
\hline \multirow{2}{*}{1} & Resiko & 99 & 41,6 & 139 & 58,4 & 238 & \multirow{5}{*}{0,000} \\
\hline & Tinggi & & & & & & \\
\hline \multirow{3}{*}{2} & Resiko & 24 & 92,3 & 2 & 7,7 & 26 & \\
\hline & Rendah & & & & & & \\
\hline & Jumlah & 123 & & 141 & & 246 & \\
\hline
\end{tabular}

Berdasarkan Tabel 6 diatas dapat dilihat bahwa dari 264 responden ibu TB berisiko tinggi dengan persalinan SC berjumlah $99(41,6 \%)$ orang lebih besar dibandingkan ibu TB beresiko dengan persalinan sectio cesarea berjumlah 24(92,3\%)

Berdasarkan uji Chi Square didapatkan nilai $\mathrm{p}$ value $=0,000<\mathrm{a} 0,05$. Artinya menunjukkan bahwa adanya hubungan yang signifikan antara tinggi badan ibu dengan persalinan sectio cesarea dengan demikian hipotesis yang menyatakan antara tinggi badan ibu dengan persalinan sectio cesarea terbukti secara statistik.

\section{c. Hubungan Malpresentasi denganPersalinan Seksio Cessaria}

Tabel 7 Distrubusi Hubungan Malpresentasi dengan Kejadian Sectio Caesarea di RSUD H Abdul Manap Kota Jambi Tahun 2019

\begin{tabular}{|c|c|c|c|c|c|c|c|}
\hline \multirow{3}{*}{$\begin{array}{l}\mathbf{N} \\
\mathbf{o}\end{array}$} & \multirow{3}{*}{$\begin{array}{c}\text { Mal } \\
\text { Prestasi }\end{array}$} & \multicolumn{4}{|c|}{$\begin{array}{c}\text { Persalinan Sectio } \\
\text { Caesarea }\end{array}$} & \multirow{3}{*}{ Total } & \multirow{3}{*}{$\begin{array}{c}P \\
\text { Value }\end{array}$} \\
\hline & & \multicolumn{2}{|c|}{ Ya } & \multicolumn{2}{|c|}{ Tidak } & & \\
\hline & & $\mathbf{N}$ & $\%$ & $\mathbf{N}$ & $\%$ & & \\
\hline 1 & Tidak & 41 & 54,7 & 34 & 45,3 & 75 & \multirow{3}{*}{0,128} \\
\hline \multirow[t]{2}{*}{2} & $\mathrm{Ya}$ & 82 & 43,4 & 107 & 56,6 & 189 & \\
\hline & Jumlah & 123 & & 141 & & 246 & \\
\hline
\end{tabular}

Berdasarkan Tabel 7 diatas dapat dilihat bahwa dari 264 responden ibu yang mengalami Malpresentasi dengan persalinan sectio cesarea brtjumlah 82 ( 43,4\%)

Berdasarkan Uji Chi Square di dapatkan nilai $\mathrm{p}$ value $=0,128<\mathrm{a} 0,05$. Artinya 
menunjukkan bahwa tidak ada hubungan yang signifikan antara partus lama dengan persalinan section caesarea dengan demikian chipotesis yang menyatakan ada hubungan antara partus lama dengan persalinan sectio cesarea tidak terbukti secara statistik

\section{PEMBAHASAN}

Penelitian ini menggunakan desain cross sectional, Penelitian ini hanya sebatas mencari antara variabel independen (Sectio Caesarea) dengan variabel independen (Umur, tinggi badan ibu dan Malpresentasi) dengan menggunakan UjiC Square serta medical record sebagai alat yang digunakan untuk mengumpulkan data melalui checklist.

Sampel penelitian adalah sebagian dari populasi yang diambil dari keseluruhan objek yang diteliti dan dianggap mewakili seluruh populasi, ${ }^{8}$ cara pengambilan dilakukan dengan cara Simple Random Sampling (Secara acak sederhana), dimana sample yaitu sebagian ibu yang melahirkan di RSUD Abdul Manap Kota Jambi Tahun 2019 berjumlah 264 orang. Pembahasan penelitian ini terdiri dari analisis univariat dan analisis bivariat dan akan diuraikan sebagai berikut :

\section{Persalinan Seksio Caesarea}

Pada analisis yang dilakukan untuk mengetahui distribusi frekuensi dan presentase dari seksio caesarea dibedakan menjadi dua kategori yaitu Ya dan Tidak.

Dari hasil analisis univariat dari 264 dapat diketahui bahwa ibu dengan diaknosa persalinan seksio cesarean sebanyak 123 $(46,6 \%)$ responden lebih kecil dibandingkan yang tidak terdiaknosa persalinan seksio.

\section{Hubungan antara Umur dengan Persalinan Sectio Caesarea RSUD Abdul Manap Kota Jambi Tahun 2019}

Pada analisis yang dilakukan untuk mengetahui distribusi frekuensi dan presentase malpresentasi yang dikelompokan menjadi dua kategori yaitu resiko tinggi dan Resiko Rendah . Dari hasil analisis data univariat di dapat bahwa dari 264 respondent dapat diketahui bahwa ibu yang Resiko Rendah sebanyak $46(17,4 \%)$ responden lebih kecil dibandingkan dengan ibu yang Resiko Tinggi sebanyak $218(82,6)$ responden.

Analisis bivariat terhadap variable tersebut didapatkan bahwa proposi 246 responden ibu yang mengalami Resiko
Rendah dengan tindakan persalinan SC sebanyak $25(54,3 \%)$ orang lebih sedikit dibandingkan dengan responden yang mengalamiResiko Tinggi dengan persalinan SC yaitu 98 (45\%). Berdasarkan uji ChiSquare didapat nilai p value $=0,318<$ a 0.05 yang berarti tidak ada hubungan antara umur dengan persalinan sectio cesarea di RSUD Abdul Manap Kota Jambi Tahun 2019 jadi analisa yang mengetahui adanya hubungan antar malpresentasi dengan persalinan sectio secarea tidak terbukti secara statistik.

Hasil penelitian ini sesuai dengan hasil penelitian Remlis Revika tahun 2013 di RSUD dr. M. Yunus Baturaja terdapat 147 orang sampel terdapat 62 orang $(55,5 \%)$ Umur dengan section sesarea dan terdapat 44 orang $(50,2 \%)$ umur resiko tinggi dengan tidak section sesarea, dan 48 orang sample terdapat 15 orang $(21,5 \%)$ yang mengalalami umur resiko tinggi dengan section sesarea dan terdapat 26 orang $(19,5 \%)$ yang resiko rendah tergolong dengan tidak section sesarea dengan kategori hubungan lemah dan $\mathrm{OR}=2,442 .{ }^{9}$

\section{Hubungan antara tinggi badan dengan persalinan Sectio Caesarea di RSUD Abdul Manap Kota Jambi Tahun 2019}

Pada analisis yang dilakukan untuk menegetahui distribusi Frekuensi dan persentase dari tinggi badan ibu yang dikelompokan menjadi dua kategori yaitu resiko tinggi (Bila TB ibu < 145) dan resiko rendah (Bila TB ibu > 145) Berdasarkan data dari analisis univariat dari 264 responden dapat diketahui bahwa TB ibu resiko tinggi sebanyak 238 (90,2\%) Responden lebih besar dibandingkan dengan TB Ibu resiko rendah sebanyak 26 Responden $(9,8 \%)$.

Dari data analisis bivariat dari 246 responden ibu $\mathrm{TB}$ beresiko tinggi dengan persalinan SC berjumlah $99(41,6 \%)$ orang lebih besar dibandingkan ibu TB beresiko rendah dengan persalinan Seksio Cesarea berjumlah 24 (92,3\%) Berdasarkan Uji ChiSquare di dapati nilai $p$ value $=0,000<\mathrm{a} 0.05$. yang berarti ada hubungan antara tinggi badan ibu dengan persalinan resiko Sectio Cesarea di RSUD H Abdul Manap Kota Jambi terbukti secara statistik.

Wanita dengan tinggi kurang dari $145 \mathrm{~cm}$ berpotensi lebih tinggi untuk memiliki panggul sempit. Tetapi apabila tinggi badan kurang dari $145 \mathrm{~cm}$, jika ukuran badan dan tubuh bayi kecil, misalnya seperti pada bayi 
lahir prematur dengan usia kehamilan 6-7 bulan, maka persalinan normal masih dimungkinkan. Sebaliknya jika tinggi badan lebih dari $145 \mathrm{~cm}$, jika ada kondisi-kondisi tertentu, bisa saja memiliki kendala untuk melahirkan normal.

4. Hubungan antara Malpresentasi dengan persalinan Sectio Secarea di RSUD H Abdul Manap Kota Jambi Tahun 2019

Pada analisis yang dilakukan untuk mengetahui distribusi frekuensi dan persentase dari Malpresentasi yang dikelompokan menjadi 2 kategori yaitu ya (Bila terdiagnosa mal prestas) dan Tidak. Berdasarkan data dari analisis univariat dari 264 responden dapat diketahui bahwa ibu yang tersiagnosa tidak Malpresentasi sebanyak $75(28,4 \%)$ responden lebih kecil dibandingkan dengan ibu yang tidakerdiagnosa Malpresentasi sebanyak 189 responden $(71,7 \%)$.

Dari 264 responden ibu mengalami Malpresentasi dengan persalinan SC berjumlah $41 \quad(54,7)$ orang lebih kecil dibandingkan ibu yang tidak mengalami tidak mal prestas dengan persalinan seksio caserea berjumlah $82(43,4 \%)$. Berdasarkan uji chisquare didapat nilai $\mathrm{p}$ value $=0,128$,a 0.05 yang berarti tidak ada hubungan antara Malpresentasi dengan persalinan seksio casarea di RSUD Abdul Manap Kota Jambi Tahun 2019 terbukti secara statistik.

Alasan Persalinan Sectio Caesarea di Kabupaten pali Tahun 2012 dapat disimpulkan bahwa alasan utama dilakukannya persalinan Sectio Caesarea adalah menolak persalinan pervaginam $(33,9 \%)$, selain partus lama caesarea $(16,5 \%)$ dan idukasi gagal $(12,4 \%)$. Persalinan secito caesarea dengan alasan menolak persalinan pervaginam. Penelitian oleh Gondo dan Sugiharto (2006) dengan persentase sebesar $34,82 \%$, sedangkan sisanya sebesar 65,18\% merupakan persalinan Sectio Caesarea dengan alasan medis. Sama halnya apa yang dikemukakan, oleh annisa (2011) melalui penelitian yang dilakukan di Rumah Dr.Adjidarmo lebak yang menyebutkan alasan terbanyak dilakukannya persalinan secito caesarea adalah ketuban pecah dini $(18,6 \%)$, kala II lama (14,7\%), partus lama $(14,0 \%)$, dan malposisi $(13,6 \%)^{10}$

\section{KESIMPULAN}

Berdasarkan hasil penelitian yang dilaksanakan di RSUD Abdul Manap Kota Jambi
Tahun 2019 dari tanggal 19 september sampai dengan 19 November 2019 dengan sampel sebanyak 264 orang, mengenai hubungan umur, Tinggi Badan, dan Malpresentasi dengan Persalinan Seksio Cessaria, maka dapat ditarik kesimpulan Tidak ada hubungan yang bermakna umur dan Malpresentasi lama secara persial dan ada hubungan dengan tinggi badan dengan persalinan casarea di RSUD Abdul Manap Kota Jambi Tahun 2019

\section{DAFTAR PUSTAKA}

1. Oxom, William , 2010 (http://repository.ump.ac.id/1962/3/DAHLIA\% 20BAB\%20II.pdf.

2. Wiknjosastri, Hanifah. 2012. Ilmu Bedah Kebidanan, Yayasan Bina Pustaka : Jakarta

3. Mochtar Rustam, 2006. Sinopsis Obsteyri Jilid1.Penerbit EGC : Jakarta.

4. Chapman, 2006, asuhan kebidanan Persalinan dan kelahiran, EGC. : Jakarta.

5. Cunninghan, 2005. Obstreti Wiliams . Vol. 1 EGC : Jakarta

6. Nugroho, dr. taufan 2010. Kasus emergency Kebidanan. Yogyakarta: Nuha Medika.

7. Profil RSUD H Abdul Manap , Jambi 2019

8. Notoatmodjo, 2007. Pendidikan dan prilaku kesehatan. Rineka cipta, jakarta.

9. Farer, 2001. Perawatan martenitas. EGC. Jakarta.

10.Kabupaten pali, 2012. Profil kesehatan Kabupaten pali.

11.Kasdu, 2003. Operasi caesar masalah dan solusinya, puspa swara : Jakarta 
